Article

\title{
Polymer Pen Lithography-Fabricated DNA Arrays for Highly Sensitive and Selective Detection of Unamplified Ganoderma Boninense DNA
}

\author{
Ekta Rani ${ }^{1,+}{ }^{(0)}$, Siti Akhtar Mohshim ${ }^{2,3}$, Muhammad Zamharir Ahmad ${ }^{3}$, \\ Royston Goodacre ${ }^{1, \ddagger(1)}$, Shahrul Ainliah Alang Ahmad ${ }^{2,4, *}$ and Lu Shin Wong $1, *($ ) \\ 1 Manchester Institute of Biotechnology and School of Chemistry, University of Manchester, \\ 131 Princess Street, Manchester M1 7DN, UK; ades.ekta@gmail.com (E.R.); \\ roy.goodacre@liverpool.ac.uk (R.G.) \\ 2 Department of Chemistry, Universiti Putra Malaysia, Serdang 43400, Selangor, Malaysia; \\ ctakhtar@gmail.com \\ 3 Biotechnology and Nanotechnology Research Centre, Malaysian Agricultural Research and Development \\ Institute, Serdang 43400, Selangor, Malaysia; zamharir@mardi.gov.my \\ 4 Institute of Advanced Technology, Universiti Putra Malaysia, UPM Serdang 43400, Selangor, Malaysia \\ * Correspondence: ainliah@upm.edu.my (S.A.A.A.); 1.s.wong@manchester.ac.uk (L.S.W.); \\ Tel.: +60-389466805 (S.A.A.A.); +44-161306 8939 (L.S.W.) \\ † Present address: Department of Physical Sciences, Central University of Punjab, Mansa Rd, Bathinda 151001, \\ Punjab, India. \\ $\ddagger$ Present address: Department of Biochemistry, Institute of Integrative Biology, University of Liverpool, \\ Crown Street, Liverpool L69 7ZB, UK.
}

Received: 26 February 2019; Accepted: 22 March 2019; Published: 25 March 2019 updates

\begin{abstract}
There is an increasing demand for lithography methods to enable the fabrication of diagnostic devices for the biomedical and agri-food sectors. In this regard, scanning probe lithography methods have emerged as a possible approach for this purpose, as they are not only convenient, robust and accessible, but also enable the deposition of "soft" materials such as complex organic molecules and biomolecules. In this report, the use of polymer pen lithography for the fabrication of DNA oligonucleotide arrays is described, together with the application of the arrays for the sensitive and selective detection of Ganoderma boninense, a fungal pathogen of the oil palm. When used in a sandwich assay format with DNA-conjugated gold nanoparticles, this system is able to generate a visually observable result in the presence of the target DNA. This assay is able to detect as little as 30 ng of Ganoderma-derived DNA without any pre-amplification and without the need for specialist laboratory equipment or training.
\end{abstract}

Keywords: polymer pen lithography; sandwich assay; genomic DNA; visual and optical detection; Ganoderma boninense

\section{Introduction}

The demand for the fabrication of micro- and nanoscale features of biomolecules such as proteins and oligonucleotides for their applications in biosensing, diagnostics, and tissue engineering is increasingly widespread [1-3]. However the lithography of nanoscale features consisting of "soft" biomolecules remains a significant challenge. Photolithography and electron beam lithography are staples of conventional nanofabrication in the semiconductor industry, but they are difficult to adapt to biomolecules because of the harsh ("hard") processing conditions used, which can include the use of short wavelength ultraviolet light or ultrahigh vacuum conditions. A common soft lithography approach that has been demonstrated for the patterning of biomolecules is microcontact printing $(\mu \mathrm{CP})$, 
which uses an elastomeric stamp to print the molecules on to the surface [4-6]. $\mu \mathrm{CP}$ offers an easy and inexpensive route for stamping soft molecules over large $\left(\mathrm{cm}^{2}\right)$ areas, under ambient conditions. However, feature fidelity is generally poor at the sub- $\mu \mathrm{m}$ scale. Furthermore, there is a lack of design flexibility, since the pattern is fixed by the design of the photolithographically fabricated master.

As an alternative, scanning probe microscopy-based methods such as dip pen lithography (DPN) offer the generation of biomolecular features with sub-100 nm resolution at or near ambient conditions $[7,8]$. DPN has also been further developed to use large arrays of probes to enable parallelised large-area fabrication [9]. However, these large "two-dimensional" DPN probe arrays are technically difficult to produce and delicate to use. To address these limitations, polymer pen lithography (PPL) was developed $[10,11]$. Instead of the cantilevered arrays of stiff probes used in DPN, PPL employs arrays of pyramidal probes consisting of silicone elastomer that are robust and inexpensive. PPL thus combines the advantages of $\mu \mathrm{CP}$ and DPN: the ability to pattern large areas with arbitrary patterns of soft materials, down to sub- $100 \mathrm{~nm}$ resolution; simple probe array preparation and robustness of use. Indeed, PPL has previously been demonstrated for the deposition of both proteins [12] and oligonucleotides [13].

In terms of end applications, it has been proposed that "arrays" of oligonucleotides offer a method for the detection of specific DNA sequences, and thus the potential for the creation of medical diagnostic kits [14,15]. Patterning of microarrays of biomolecules is limited in application due to the requirement for relatively large sample volumes, prolonged incubation time, and a relatively poor limit of detection. Arrays of nanoscale features can offer better performance with detection down to $\sim 10^{6}$ copies compared to microscale patterns (with features typically in the 10s of $\mu \mathrm{m}$ ) [16] or non-patterned surfaces (i.e., whole surface covered) [17]. Apart from the device performance, such oligonucleotide arrays also offer the benefit of ease of use (without the need for specialist training or equipment), portability and tolerance to a wide range of environmental conditions. These aspects are particularly important when considering applications in the agricultural sector and in the developing world, which typically require diagnostics outside specialist laboratories (i.e., in the field).

As a specific example of an application in tropical agriculture, there is a need for convenient methods for the detection of the fungal pathogen Ganoderma boninense, which causes basal stem rot disease in oil palms [18-20]. Once established, this disease is the major cause of yield loss in this crop, and early detection would enable isolation of the infected palms [18]. However, early diagnosis is difficult because the disease is symptomless in early infection and G. boninense has various resting stages where there is apparently little change to the host plant [20]. Furthermore, G. boninense is a soil-borne organism, and its detection in soil samples would also enable the growers to manage the land by fallowing or sanitation before replanting [20].

Molecular methods to detect G. boninense based on antibodies [21-23] and electrochemical sensors [24-28] have been employed. Various non-molecular methods based on density and ultrasonic detection [29], spectral imaging [30-32], and backscattering measurements [33] have also been used in an attempt to detect $G$. boninense. However, these detection methods are either not species-specific, and/or possess practical disadvantages in regards to complexity, cost and the need for specialist training.

Herein, the use of PPL to produce oligonucleotide arrays is reported, which together with DNA-gold nanoparticle (DNA-AuNP) conjugates, provide a sensitive and selective detection of unamplified genomic DNA of G. boninense extracted from mycelial cultures of this organism. Using a sandwich assay format [34], in the presence of the target DNA sequence from the target organism, the complementary "capture" DNA-AuNPs are immobilised on to the "reporter" surface arrays (Figure 1). This immobilisation results in an alteration of the surface properties that can be visualised optically, and with high sensitivity and selectivity. 


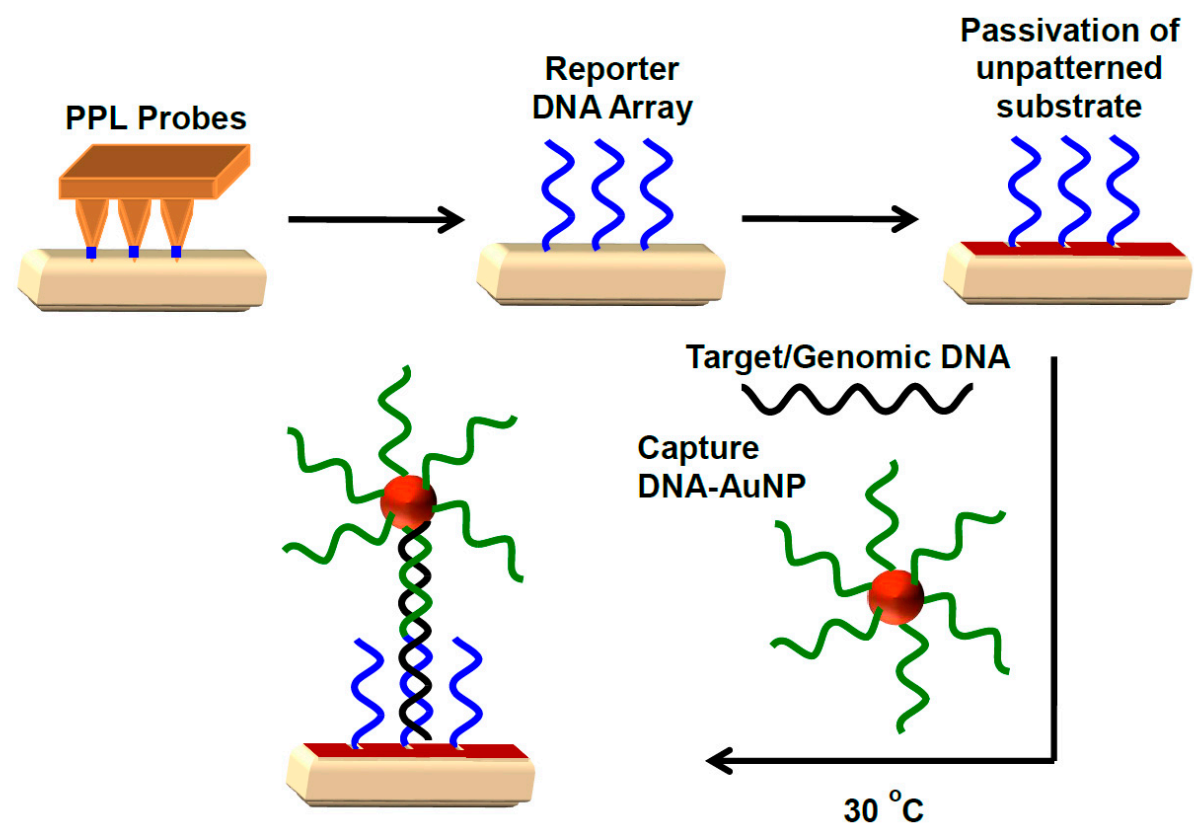

Figure 1. Schematic diagram illustrating the immobilisation of reporter DNA using polymer pen lithography (PPL) probes on a Au surface followed by the passivation of unpatterned substrate with triethylene glycol mono-11-mercaptoundecyl ether. In the presence of capture DNA-AuNPs, the target DNA forms a sandwich assay that can be detected optically.

\section{Experimental Section}

\subsection{Materials and Equipment}

All chemical reagents were purchased from Sigma Aldrich, Merck or Thermo Fisher Scientific and used as supplied. All reagents were of analytical grade. $20 \mathrm{~nm}$ AuNP colloid (in $0.1 \mathrm{mg} \mathrm{mL}^{-1}$ sodium citrate) at a concentration of 1 optical density (OD) unit @ 520 nm were purchased from Kestrel Biosciences (Pathumthani, Thailand). Sterile deionised water was used for all the experiments. High-performance liquid chromatography (HPLC) purified single-stranded DNA (ssDNA) of the target sequence, "capture" (with a 5' S-S C6 disulfide linker) and "reporter" (with a 3' S-S C3 disulfide linker) were purchased from IDT and supplied in the lyophilised form. The target ssDNA sequence corresponds to a fragment of the G. boninense internal transcribed spacer 1 (ITS1) within the $18 \mathrm{~S}$ ribosomal gene with the National Center for Biotechnology Information (NCBI) GenBank accession number EU701010. Sequences of the target, capture and reporter ssDNA are listed in Table 1.

Table 1. List of ssDNA sequences used in these experiments.

\begin{tabular}{cc}
\hline Name & Sequence $\left(\mathbf{5}^{\prime} \rightarrow \mathbf{3}^{\prime}\right.$ ) \\
\hline Capture probe & (Thiol C6)CCTGCTGCGTTCTTCTTCAT \\
\hline Reporter probe & CGATGCGAGAGCCAA(Thiol C3) \\
\hline Target & TTGGCTCTCGCATCGATGAAGAAGAACGCAGCAGG \\
\hline
\end{tabular}

NEXTERION ${ }^{\circledR}$ glass slides were purchased from Schott (Jena, Germany). Au film deposition was performed using BOC Edwards Auto 500 electron beam deposition system. The $\mathrm{O}_{2}$ plasma treatment was performed using Harrick Plasma PDC-32G plasma cleaner (Ithaca, NY, USA). Spin-coating was performed with a Laurell Technologies WS-650-23NPP spin-coater (North Wales, PA, USA). Polymer pen lithography and atomic force microscopy (AFM) were performed on a custom-built atomic force microscope with a 5-axis sample stage (Nanosurf AG, Liestal, Switzerland) equipped with an automated alignment algorithm reported previously $[35,36]$. 
The non-complementary genomic DNA was extracted using an Exgene Plant SV Mini Kit (GeneAll Biotechnology Co. Ltd., Seoul, Korea). Sonication of the extracted DNA was performed with Qsonica Q125 sonicator (Cole-Parmer, Vernon Hills, IL, USA). A NanoDrop ND-1000 (NanoDrop Technologies LLC., Wilmington, DE, USA) was used to measure the concentration of genomic DNA at $260 \mathrm{~nm}$.

\subsection{Preparation of Capture DNA-AuNP Conjugates}

Capture DNA-AuNP conjugates were prepared as previously described [37] with a few modifications. Specifically, the capture probe ssDNA was dissolved in water to a concentration of $100 \mu \mathrm{M}$. A $65 \mu \mathrm{L}$ aliquot of the capture probe DNA was mixed with $34 \mu \mathrm{L}$ of sterile deionised water and $1 \mu \mathrm{L}$ of $10 \mathrm{mM}$ aqueous tris(2-carboxyethyl)phosphine hydrochloride (TCEP) solution and incubated at room temperature (RT: $\sim 27^{\circ} \mathrm{C}$ in Kuala Lumpur) for $1.5 \mathrm{~h}$ to reduce the disulfide bond in the capture DNA. The mixture was then added to $1 \mathrm{~mL}$ of AuNP colloid and incubated at RT for $16 \mathrm{~h} .135 \mu \mathrm{L}$ of sterile deionised water was added to the mixture. $13 \mu \mathrm{L}$ of $5 \mathrm{M} \mathrm{NaCl}$ was added to this mixture and subjected to ultrasonic agitation for $10 \mathrm{~s}$, then allowed to stand at RT for $1 \mathrm{~h}$. This process of addition of $\mathrm{NaCl}$, agitation and standing were performed five times in total, until a final concentration of $0.25 \mathrm{M} \mathrm{NaCl}$ was achieved. The final colloidal solution was allowed to stand at RT for $24 \mathrm{~h}$ and then centrifuged at $17,000 \times g$ for $30 \mathrm{~min}$. The supernatant was decanted, and the pellet was resuspended in phosphate-buffered saline (PBS) diluted to half-strength (i.e., final composition $5.9 \mathrm{mM}$ phosphate buffer, $68.5 \mathrm{nM} \mathrm{NaCl}, 1.35 \mathrm{mM} \mathrm{KCl}, \mathrm{pH} 7.4)$ containing $0.01 \% v / v$ Tween 20. This process of centrifugation, decanting and resuspension was repeated three times to remove the unreacted DNA. The final pellet of AuNP was re-suspended in $300 \mu \mathrm{L}$ of PBS buffer ( $\mathrm{pH}$ 7.4).

\subsection{Preparation of Reporter DNA Arrays by PPL}

\subsubsection{Preparation of Materials}

$10 \mathrm{~nm}$ Au films (with a $2 \mathrm{~nm}$ Ti adhesion layer) were deposited on to glass slides by electron beam deposition according to standard procedures at a rate of $0.03 \mathrm{~nm} \mathrm{~s}^{-1}$ under $5 \times 10^{-6}$ Torr. The elastomeric PPL probe arrays were prepared according to the procedures previously reported [35]. For the purposes of this research, probe arrays of $13 \times 13 \mathrm{~cm}^{2}$ were used with an interprobe pitch of $100 \mu \mathrm{m}$. Prior to lithography the probe arrays were treated with $\mathrm{O}_{2}$ plasma (500-600 mTorr at maximum RF power for $2 \mathrm{~min}$ ).

The reporter ssDNA that was to be printed was prepared by reconstituting the lyophilised DNA disulfide with deionised water (to a concentration of $100 \mu \mathrm{M}$ ). $49 \mu \mathrm{L}$ of this solution was then mixed with $1 \mu \mathrm{L}$ of $20 \mathrm{mM}$ aqueous solution of TCEP for $2 \mathrm{~h}$ to reduce the disulfide bond. Two formulations of "ink" solution containing this TCEP-treated DNA were then prepared and deposited on to the PPL arrays:

Ink 1: The reporter ssDNA solution was diluted to a final concentration of $50 \mu \mathrm{M}$ in a solution containing $90 \% \mathrm{DMF} / 10 \%$ water and $0.3 \mathrm{M} \mathrm{MgCl}_{2}$. The PDMS probe array was dipped for $10 \mathrm{~s}$ into this solution and dried under a stream of $\mathrm{N}_{2}$ gas; or spin-coated at 3500 RPM for $3 \mathrm{~min}$ [38].

Ink 2: The reporter ssDNA solution was diluted to a final concentration of $50 \mu \mathrm{M}$ in a trehalose-containing buffer $(400 \mathrm{mM}$ potassium phosphate buffer of $\mathrm{pH} 7.0,0.5 \%$ w/v trehalose dihydrate, $0.1 \% v / v$ Tween 20 , and $20 \% v / v$ glycerol). $20 \mu \mathrm{L}$ ink was dropped onto the PPL array and spin coated at $3500 \mathrm{RPM}$ for $3 \mathrm{~min}$ [13].

\subsubsection{PPL Printing of Reporter DNA Arrays}

The ink-coated probe array was attached to the middle of the probe holder, and the probe holder was mounted on to the AFM. The Au coated glass slide was mounted in the middle of the AFM sample stage and the alignment of the probe array with the slide was performed [35] with the "Angle Step" parameter set at $0.15^{\circ}$ and the "Coarse Step" and "Fine Step" settings at 0.6 and $0.2 \mu \mathrm{m}$, respectively. After the alignment process was completed, the AFM atmospheric isolation chamber was engaged and set to a relative humidity of $65 \%$, a temperature of $23{ }^{\circ} \mathrm{C}$ and a gas flow rate of $500 \mathrm{~mL} \mathrm{~min}-1$. 
Once desired humidity was reached, the coated probes were moved to the desired position on the substrate and the lithography was performed for the chosen pattern with a dwell time of $1 \mathrm{~s}$ per dot feature. Two different patterns were printed whereby each probe produced; (i) a single grid of $25 \times 25$ dot features with an interfeature pitch of $3 \mu \mathrm{m}$; (ii) a $2 \times 2$ matrix of arrays (distance between two grids is $20 \mu \mathrm{m}$ ), with each array consisting of a $10 \times 10$ dot features with a pitch of $2 \mu \mathrm{m}$. Post-lithography, the gold substrates were immediately imaged by AFM and optical microscopy, before being washed with water and dried with an $\mathrm{N}_{2}$ stream.

The substrates used for subsequent hybridisation experiments were immersed in a solution of triethylene glycol mono-11-mercaptoundecyl ether (1 $\mathrm{mM}$ in ethanol) for $1 \mathrm{~min}$ and air dried.

\subsection{Extraction of Genomic DNA}

Fruiting bodies of Ganoderma were collected from an oil palm plantation located in Lahad Datu, Malaysia. Isolation of the pure culture of $G$. boninense was carried out on potato dextrose agar plates using a previously published protocol [39]. The samples were incubated in the dark at $25-28^{\circ} \mathrm{C}$ during growth of the culture.

Extraction of the genomic DNA was performed using a previously reported protocol [40] with some modifications. In brief, approx. $100-500 \mathrm{mg}$ of the fungal mycelia was homogenized using a disposable micro pestle with $400 \mu \mathrm{L}$ DNA extraction buffer $(200 \mathrm{mM}$ Tris, $250 \mathrm{mM} \mathrm{NaCl}, 25 \mathrm{mM}$ EDTA, $0.5 \% w / v$ SDS, pH 8.5) and the homogenate shaken at $65^{\circ} \mathrm{C}$ for $10 \mathrm{~min} .130 \mu \mathrm{L}$ of $3 \mathrm{M}$ sodium acetate ( $\mathrm{pH}$ 5.2) was added, the lysate incubated at $-20^{\circ} \mathrm{C}$ for $10 \mathrm{~min}$, then separated by centrifugation $\left(16,100 \times g\right.$ at $4{ }^{\circ} \mathrm{C}$ for $\left.15 \mathrm{~min}\right)$. The clear supernatant was decanted, into which an equal volume of isopropanol was mixed and incubated at $-20^{\circ} \mathrm{C}$ for $10 \mathrm{~min}$. This mixture was then centrifuged (3300 $\times \mathrm{g}$ at $4{ }^{\circ} \mathrm{C}$ for $20 \mathrm{~min}$ ), the supernatant discarded and the pellet was washed with $100 \%$ and then $70 \%$ ethanol. The pellet was air dried for $10 \mathrm{~min}$ at $40{ }^{\circ} \mathrm{C}$ and resuspended in $100 \mu \mathrm{L}$ of sterile deionised water.

The non-complementary genomic DNA was extracted from soya beans using DNA extraction kit according to the kit manufacturer's instructions.

The extracted DNA was subjected to sonication on ice (25\% of amplitude, $10 \mathrm{~s}$ pulse and $3 \mathrm{~s}$ rest) to shear the DNA into smaller fragments [41]. Concentration of genomic DNA was measured post-sonication by ultraviolet-visible (UV-Vis) spectrometry.

\subsection{Hybridisation Experiment on PPL Arrays}

For the hybridisation experiment, $100 \mu \mathrm{L}$ of capture DNA-AuNP colloid (from Section 2.2) was centrifuged at $17,000 \times g$ for $10 \mathrm{~min}$, the supernatant discarded and the pellet resuspended in $99 \mu \mathrm{L}$ of hybridisation buffer consisting of $10 \mathrm{mM}$ sodium phosphate buffer, $300 \mathrm{mM} \mathrm{NaCl}$ at $\mathrm{pH}$ 7.0. To this mixture, $1 \mu \mathrm{L}$ of target ssDNA was added for the hybridisation experiment.

For genomic DNA, the pellet of AuNP was resuspended in $97.5 \mu \mathrm{L}$ of hybridisation buffer and $2.5 \mu \mathrm{L}$ of genomic DNA was added for the hybridisation experiment.

This solution was allowed to stand under the appropriate conditions (see Sections 3.2 and 3.3) and was then dropped on to a PPL-printed reporter DNA array slide and incubated for the appropriate time. The slide was then washed with $1 \mathrm{M}$ ammonium acetate and air dried. Post-hybridisation patterns were visualised using an optical microscope or visual examination.

\section{Results and Discussion}

\subsection{PPL Fabrication of Reporter DNA Probe Arrays}

In order to produce the DNA arrays, PPL was employed to print the thiolated DNA sequences on to gold-coated slides, as this enabled the convenient and rapid generation $\mathrm{cm}^{2}$ areas of patterns. For this purpose, two DNA "ink" formulations were tested, which were based on previous reports of DNA printing with either DPN [38] or PPL [13] (Ink formulation 1 and 2 respectively; see Section 2.3.1). 
Ink 1, consisting of a DMF/aqueous formulation, was generally found not to wet the PPL probe arrays uniformly and thus did not result in the deposition of the DNA on to the gold surface, as evidenced by the lack of observable features by either AFM or optical microscopy (Supplementary Figure S1 in Supplementary Materials). This same result was observed regardless of whether the ink was dip- or spin-coated on to the probe arrays.

Next ink 2 was tested, which consisted of a buffer with trehalose added as a wetting agent. In contrast to ink 1, spin coating of ink 2 gave a uniform spreading of the ink on to the probe arrays. Using this ink loading method, the subsequent PPL of a $2 \times 2$ grid matrix (each grid consisting $10 \times 10$ dots) was performed. AFM imaging post-lithography clearly displayed the desired patterning (Figure 2a,b), which could also be visualised by optical microscopy (Figure 2c). Under the lithography conditions used, the individual dots with a full width at half maximum of $\sim 1.0 \pm 0.2 \mu \mathrm{m}$ were observed by AFM. In the negative control experiment, when the same lithography procedure was performed with the buffer mixture but with the DNA omitted, no features were observed by either AFM or light microscopy. The surface substrates were then washed with water and subsequent imaging showed that these features were no longer visible by optical microscopy. This suggests that features observed before washing are composed primarily of the trehalose and buffer salts along with reporter DNA, which upon washing removed these excess ink components, leaving the monolayer of thiolated DNA on the surface. Notably, the features were also no longer observable post-washing even by AFM, which was attributed to both a decrease in feature height and increased roughness of the substrates post-washing.

Prior to the hybridisation experiments, the printed and washed substrates were immersed in a solution of triethylene glycol mono-11-mercaptoundecyl ether in order to passivate the unprinted areas and prevent non-specific adsorption of biomolecules.
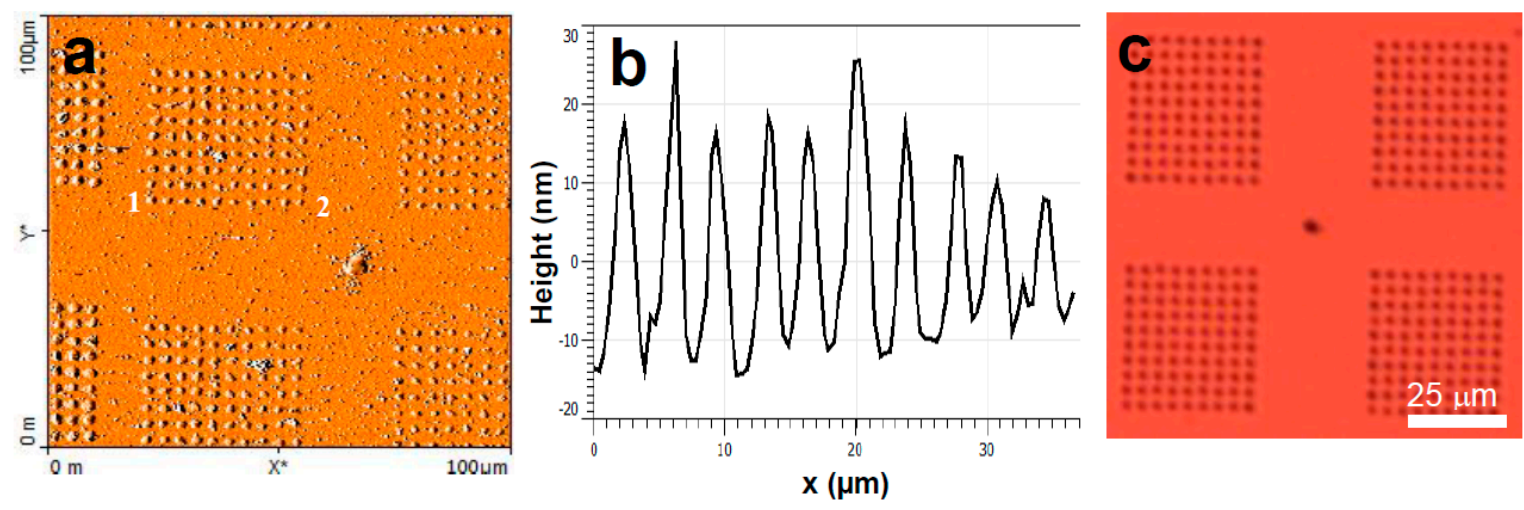

Figure 2. (a) Representative atomic force microscopy (AFM) topography image of a substrate patterned with reporter DNA dissolved in trehalose buffer, (b) representative corresponding cross-section profile along the line between points 1 and 2 marked in (a), and (c) representative optical microscopy image of a substrate patterned with reporter DNA dissolved in trehalose buffer.

\subsection{The Hybridisation of Patterned Substrates with Single-Stranded Target DNA}

As an initial evaluation of the arrays, the detection of a short synthetic ssDNA fragment corresponding to a G. boninense gene was attempted. Adapting a previously reported procedure [38], two possible approaches were tested: (i) mixing of the target DNA sample with the capture DNA-AuNP conjugates and direct application on to the PPL-printed reporter DNA arrays; or (ii) incubating the target DNA and DNA-AuNP conjugates overnight before application on to the arrays. In both cases, 10 pmol of target ssDNA ( $10 \mu \mathrm{M}$ in $1 \mu \mathrm{L}$ of analyte sample made up to $100 \mu \mathrm{L}$ of hybridisation solution added to the array) and arrays with continuous $25 \times 25$ dot grids were used. After a $3 \mathrm{~h}$ exposure to the hybridisation solution, the arrays were washed and examined by optical microscopy.

It was found that faint features were observable only when the target DNA was pre-incubated overnight with the DNA-AuNPs prior to immobilisation on to the array slide (Figure 3a), while the 
procedure that did not involve this incubation step did not give any features. The poor visibility was thought to be due to insufficient binding of the target (and pre-hybridised reporter DNA-AuNPs) on to the reporter DNA arrays. Thus, in order to improve the visibility of the features, after the mixture was drop-casted on to the array a heating step was incorporated, either $30^{\circ} \mathrm{C}$ for $3 \mathrm{~h}, 50{ }^{\circ} \mathrm{C}$ for $3 \mathrm{~h}$ or $50{ }^{\circ} \mathrm{C}$ for $1 \mathrm{~h}$; followed by a cooling period of $10 \mathrm{~min}$ at RT prior to examination by optical microscopy. It was found that only the experiment involving the $30^{\circ} \mathrm{C}$ heating gave clearer features that were organised into grid-like squares that were consistent with the PPL-printed pattern (Figure 3b). The other two heating regimes gave no visible features at all, suggesting that excessive heating prevented binding to the array.
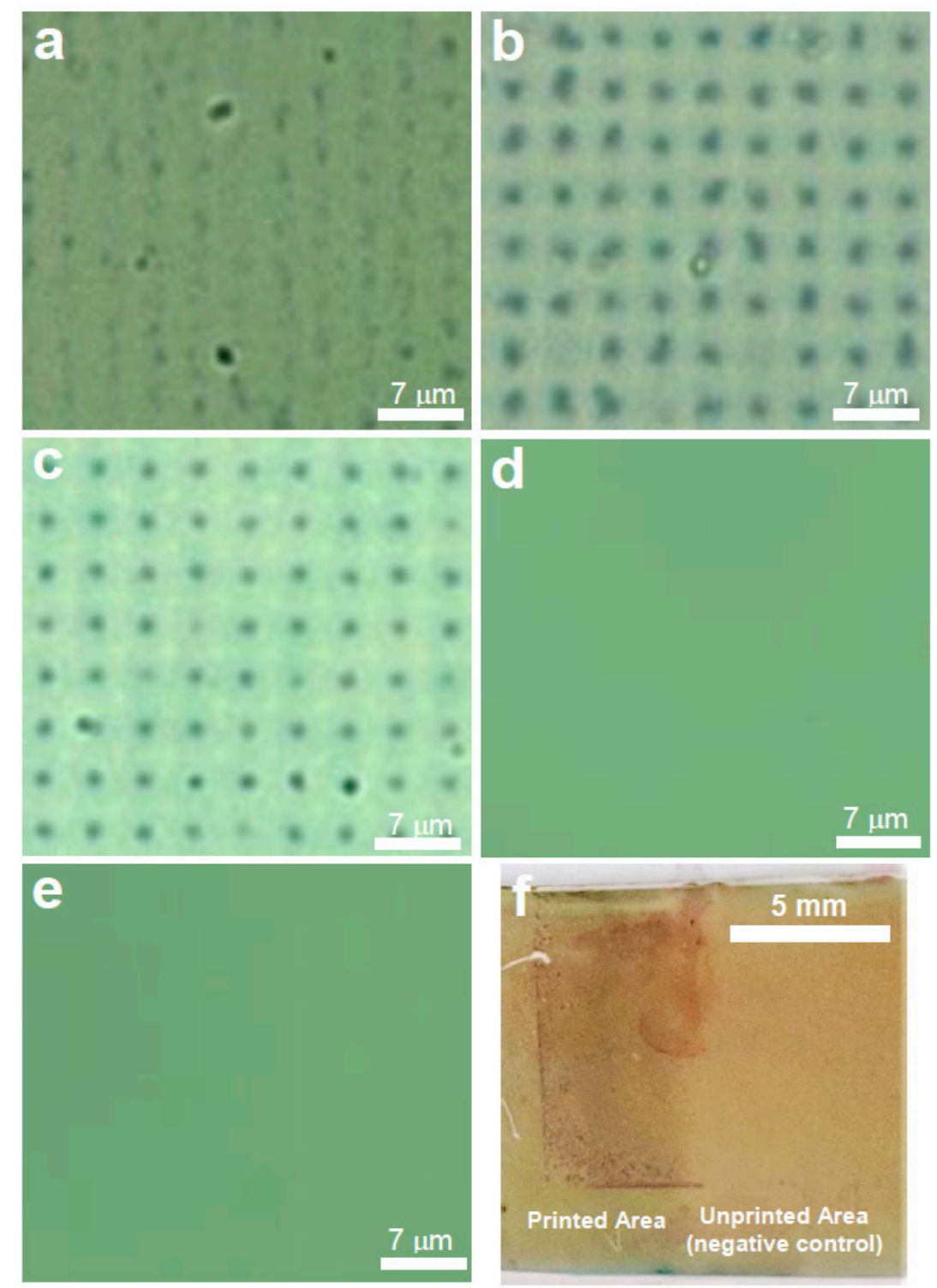

Figure 3. Representative optical microscopy images $(40 \times$ magnification $)$ for immobilisation experiments on arrays with capture DNA-AuNPs and analyte. In (a), 10 pmol of target ssDNA was hybridised with the DNA-AuNPs at room temperature (RT) overnight and applied to the DNA array for $3 \mathrm{~h}$ at RT. In (b), 10 pmol of target ssDNA was hybridised with the DNA-AuNPs at RT overnight and applied to the DNA array for $3 \mathrm{~h}$ at $30^{\circ} \mathrm{C}$. In (c), 5 pmol of target ssDNA was tested using the same conditions as (b). In (d,e), only DNA-AuNPs or only 10 pmol target ssDNA was added, respectively, using the same conditions as (b). Figure (f) shows a photographic image of the slide post hybridisation using the conditions in (b). 
Similar results could also be achieved with $5 \mathrm{pmol}(5 \mu \mathrm{M}$ in $1 \mu \mathrm{L}$ of analyte sample) corresponding to approx. $3.0 \times 10^{12}$ copies of the gene (Figure $3 \mathrm{c}$ ). These features remained visible even after several washes, indicating that the attachment to the arrays was robust. Two negative control experiments were also performed, whereby only the capture DNA-Au NP conjugates or only the target DNA were added to the arrays. In both these cases, no features were observed (Figure 3d,e).

Hybridisation of the complementary target DNA with arrays were also observable by the naked eye as a darker area on the array when it was held at a $\sim 45^{\circ}$ angle (Figure $3 \mathrm{f}$ ), which was clearly differentiated from the unprinted area.

\subsection{Detection, Sensitivity and Selectivity for Genomic DNA of G. Boninense}

Having demonstrated the general procedure and generation of these arrayed nanomaterials, the detection of genomic DNA extracted from cell culture was then investigated.

In the initial investigation a $400 \mathrm{ng}$ (in a $2.5 \mu \mathrm{L}$ sample) of genomic DNA was tested, corresponding to approx. $5.8 \times 10^{6}$ copies of the G. boninense genome (see SI for details of calculations). However, in this case the mixture of the sample DNA and capture DNA-AuNPs was heated to $95^{\circ} \mathrm{C}$ for $5 \mathrm{~min}$ (to denature the double-stranded genomic DNA and enable binding with the capture DNA) and allowed to cool for $1 \mathrm{~h}$, prior to deposition on to the reporter array as noted above (see Section 3.3). Optical microscopy post-washing showed the presence of dot patterns with good contrast corresponding to the originally PPL-printed pattern (Figure 4a), which indicated successful capture of the genomic DNA.
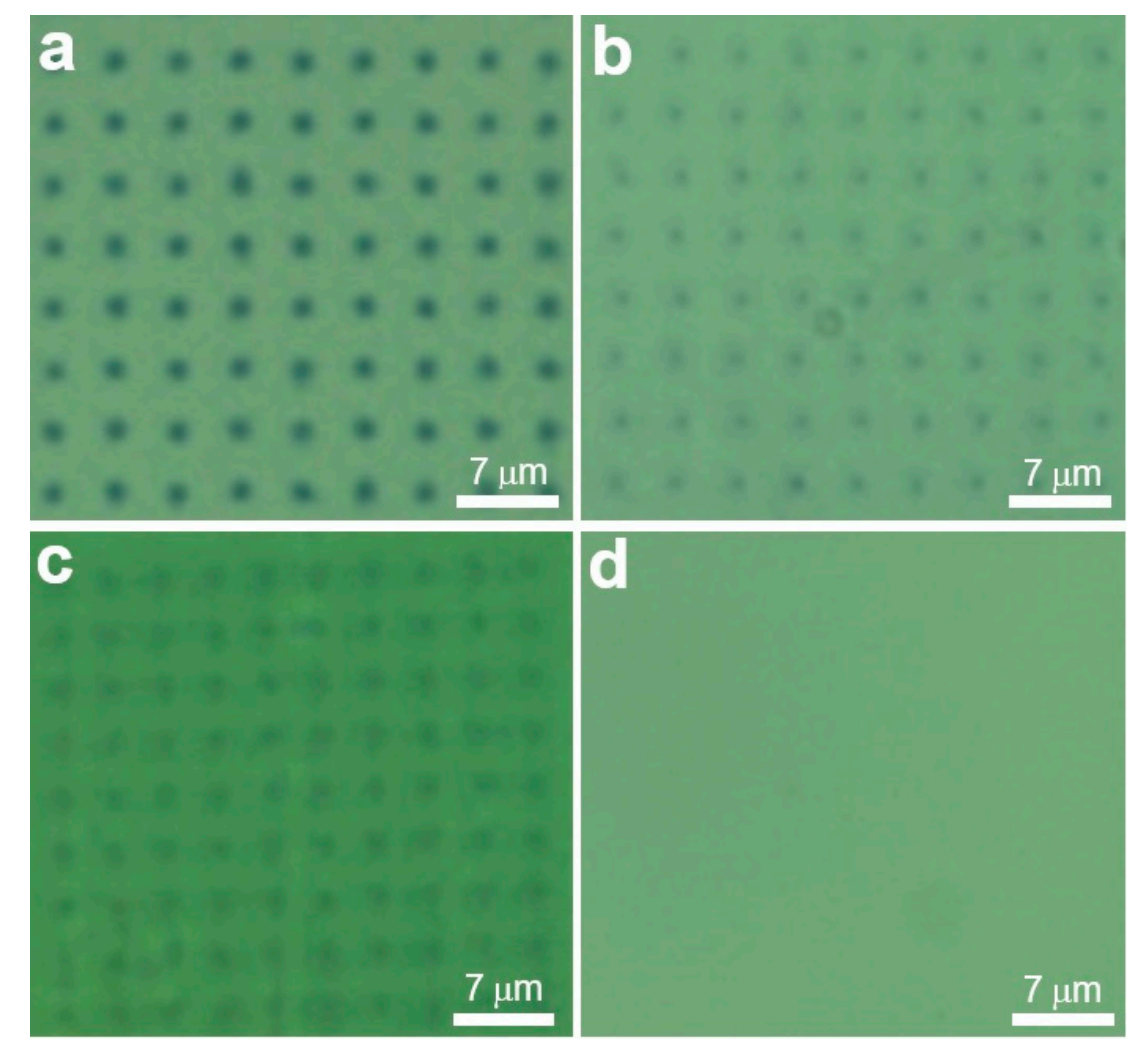

Figure 4. Representative optical microscopy images $(40 \times$ magnification $)$ for immobilisation experiments on arrays with capture DNA-AuNPs and genomic DNA extracted from G. boninense mycelia, using (a) $400 \mathrm{ng}$ (b) $160 \mathrm{ng}$, and (c) $30 \mathrm{ng}$ and (d) $225 \mathrm{ng}$ of non-complementary DNA extracted from soya bean. Genomic DNA was mixed with the DNA-AuNPs at $95^{\circ} \mathrm{C}$ for $5 \mathrm{~min}$ followed by $1 \mathrm{~h}$ cooling at RT to allow hybridisation. The mixture was then applied to arrays for $3 \mathrm{~h}$ at $30^{\circ} \mathrm{C}$ followed by $10 \mathrm{~min}$ cooling at RT prior to observation. 
To further investigate the sensitivity of this method, a further series of genomic DNA amounts (160, 30 and $3 \mathrm{ng})$ were tested. Positive results were obtained for $160 \mathrm{ng}\left(2.4 \times 10^{6}\right.$ copies $)$ and $30 \mathrm{ng}$ $\left(4.4 \times 10^{5}\right.$ copies), but not for the lowest amount of genomic DNA (Figure $\left.4 \mathrm{~b}, \mathrm{c}\right)$. However, it should be noted that the observed detection range is subject to a degree of uncertainty for at least two reasons. Firstly, each copy of the G. boninense genome includes many copies of the ribosomal $18 \mathrm{~S}$ gene, of which the absolute number is poorly defined (typically 100s) [42]. Secondly, the extracted DNA samples are subjected to ultrasonic shearing in order to generate smaller fragments that are compatible with this assay. If the fragmentation occurs within the target sequence, these fragments are unlikely to undergo hybridisation with the capture and reporter probes. Nevertheless, this level of sensitivity is likely to be facilitated by ordered orientation [43] of the capture and reporter strands, which enable efficient hybridisation and immobilisation of the target strands.

Finally, in order to study the selectivity of this method, a sample of genomic DNA that does not contain a complementary sequence to the capture and reporter sequences was tested using DNA samples extracted for soy beans. Here, even samples containing up to $225 \mathrm{ng}$ of soya bean DNA gave a negative result, as evidenced by a lack of observable features on the array (Figure $4 \mathrm{~d}$ ).

\section{Conclusions}

In summary, a method has been developed for the label-free, sensitive and sequence selective detection of DNA sequences from biologically extracted samples, without the need for polymerase chain reaction (PCR) amplification of the sample DNA material. Crucially, hybridisation of complementary target/genomic DNA with DNA arrays and DNA-AuNPs can be observed with the naked eye. As an exemplar, positive results are obtained down to approx. $30 \mathrm{ng}$ of genomic DNA from G. boninense mycelial tissue. This result is significant in comparison to other methods, which typically require the use of the PCR for the amplification of the DNA samples to produce sufficient copy numbers for detection $[44,45]$.

This method relies on a "sandwich" assay where the target DNA is immobilised between DNA-AuNP conjugates and a DNA array on a surface. Key to the development of this method are the DNA arrays that were rapidly and conveniently fabricated using PPL. The patterned surface generated by this lithography method facilitated clear identification of a positive result by presenting a clear contrast between the printed areas where the AuNPs aggregated, and the unprinted areas. Although the fabrication of the DNA arrays involves the use of PPL that does require specialist equipment and training, once the arrays are produced these are stable, portable and easy to use in the field.

In principle, a further enhancement of the assay sensitivity could be obtained through the use of silver enhancement of the deposited AuNPs [34]. The current limitations of this assay are the need for some pre-treatment of the DNA and a heating step for dehybridisation. Future work will, therefore, be aimed at the development of chemical and isothermal methods for DNA processing, to enable its application directly from homogenised tissue samples.

Supplementary Materials: The following are available online at http:/ / www.mdpi.com/2073-4360/11/3/561/s1, Supplementary document showing the supplementary figure of PPL performed using ink $\mathbf{1}$ and the calculations for genome copy number.

Author Contributions: Conceptualisation, S.A.A.A., L.S.W.; Methodology, E.R., S.A.M.; Formal Analysis, E.R., S.A.M., L.S.W.; Investigation, E.R., S.A.M.; Resources, M.Z.A., R.G., S.A.A.A., L.S.W.; Writing-Original Draft Preparation, E.R., S.A.M.; Writing-Review and Editing, E.R., R.G., M.Z.A., S.A.A.A., L.S.W.; Supervision, M.Z.A., S.A.A.A., L.S.W.; Project Administration, S.A.A.A., L.S.W.; Funding Acquisition, R.G., S.A.A.A., L.S.W.

Funding: The authors thank the British Council Newton Fund for support under contracts 216196834 and 6388400; and the HEFCE N8 Agrifood Programme. LSW thanks the UK Engineering and Physical Sciences Research Council for support under grants EP/K024485/1 and EP/K011685/1. SAAA thanks Universiti Putra Malaysia for support under grant 9647600.

Acknowledgments: The authors thank the members of Biotechnology and Nanotechnology Research Centre (MARDI) and Nor Hidayat Yusof (UPM) for technical assistance, and Michael R. Roberts (University of Lancaster, UK) for scientific advice and reviewing. 
Conflicts of Interest: The authors declare no conflicts of interest.

\section{References}

1. Tran, H.; Killops, K.L.; Campos, L.M. Advancements and challenges of patterning biomolecules with sub-50 nm features. Soft Matter 2013, 9, 6578-6586. [CrossRef]

2. Schmidt, R.C.; Healy, K.E. Controlling biological interfaces on the nanometer-length scale. J. Biomed. Mater. Res. A 2009, 90, 1252-1261. [CrossRef]

3. Kim, D.-H.; Lee, H.; Lee, Y.K.; Nam, J.-M.; Levchenko, A. Biomimetic nanopatterns as enabling tools for analysis and control of live cells. Adv. Mater. 2010, 22, 4551-4566. [CrossRef]

4. Kumar, A.; Whitesides, G.M. Features of gold having micrometre to centimetre dimensions can be formed through a combination of stamping with an elastomeric stamp and an alkanethiol 'ink' followed by chemical etching. Appl. Phys. Lett. 1993, 63, 2002-2004. [CrossRef]

5. Kumar, A.; Biebuyck, H.A.; Whitesides, G.M. Patterning self-assembled monolayers: Applications in materials science. Langmuir 1994, 10, 1498-1511. [CrossRef]

6. Jang, M.G.; Nam, Y. Agarose-assisted micro-contact printing for high-quality biomolecular micro-patterns. Macromol. Biosci. 2015, 15, 613-621. [CrossRef]

7. Salaita, K.; Wang, Y.; Mirkin, C.A. Applications of dip-pen nanolithography. Nat. Nanotechnol. 2007, 2, 145-155. [CrossRef] [PubMed]

8. Wu, C.C.; Reinhoudt, D.N.; Otto, C.; Subramaniam, V.; Velders, A.H. Strategies for patterning biomolecules with dip-pen nanolithography. Small 2011, 7, 989-1002. [CrossRef]

9. Mirkin, C.A. The power of the pen: Development of massively parallel dip-pen nanolithography. ACS Nano 2007, 1, 79-83. [CrossRef]

10. Huo, F.; Zheng, Z.; Zheng, G.; Giam, L.R.; Zhang, H.; Mirkin, C.A. Polymer pen lithography. Science 2008, 321, 1658-1660. [CrossRef]

11. Brinkmann, F.; Hirtz, M.; Greiner, A.M.; Weschenfelder, M.; Waterkotte, B.; Bastmeyer, M.; Fuchs, H. Interdigitated multicolored bioink micropatterns by multiplexed polymer pen lithography. Small 2013, 9, 3266-3275. [CrossRef]

12. Zheng, Z.; Daniel, W.L.; Giam, L.R.; Huo, F.; Senesi, A.J.; Zheng, G.; Mirkin, C.A. Multiplexed protein arrays enabled by polymer pen lithography: Addressing the inking challenge. Angew. Chem. Int. Ed. 2009, 48, 7626-7629. [CrossRef]

13. Kumar, R.; Weigel, S.; Meyer, R.; Niemeyer, C.M.; Fuchs, H.; Hirtz, M. Multi-color polymer pen lithography for oligonucleotide arrays. Chem. Commun. 2016, 52, 12310-12313. [CrossRef]

14. Roth, S.B.; Jalava, J.; Ruuskanen, O.; Ruohola, A.; Nikkari, S. Use of an oligonucleotide array for laboratory diagnosis of bacteria responsible for acute upper respiratory infections. J. Clin. Microbiol. 2004, 42, 4268-4274. [CrossRef]

15. Jain, K.K. Applications of nanobiotechnology in clinical diagnostics. Clin. Chem. 2004, 53, $2002-2007$. [CrossRef] [PubMed]

16. Chen, L.; Li, J. Nanotechnology: Moving from microarrays toward nanoarrays. In Methods in Molecular Biology: Microarrays, 2nd ed.; Rampal, J.B., Ed.; Humana Press: New York, NY, USA, 2007; Volume 1, pp. 411-436.

17. Wong, L.S.; Khan, F.; Micklefield, J. Selective covalent protein immobilization: Strategies and applications. Chem. Rev. 2009, 109, 4025-4053. [CrossRef] [PubMed]

18. Ho, Y.W.; Nawawi, A. Ganoderma boninense pathogen from basal stem rot of oil palm (Elaeis guineensis) in Peninsular Malaysia. Pertanika 1985, 8, 425-428.

19. Susanto, A.; Sudharto, P.S.; Purba, R.Y. Enhancing biological control of basal stem rot disease Ganoderma boninense in oil palm plantations. Mycopathologia 2005, 159, 153-157. [CrossRef] [PubMed]

20. Hushiarian, R.; Yusof, N.A.; Dutse, S.W. Detection and control of Ganoderma boninense: Strategies and perspectives. SpringerPlus 2013, 2, 555. [CrossRef]

21. Darmono, T.W.; Suharyanto, A. Recognition of field materials of Ganoderma sp. associated with basal stem rot in oil palm by a polyclonal antibody. Menara Perkeb. 1995, 63, 15-22. 
22. Shamala, S.; Chris, D.; Sioban, O.; Idris, A. Preliminary studies on the development of monoclonal antibodies against mycelia of Ganoderma boninense, the causal pathogen of basal stem rot of oil palm. Mal. J. Microbiol. 2006, 2, 30-34.

23. Madihah, A.Z.; Idris, A.S.; Rafidah, A.R. Polyclonal antibodies of Ganoderma boninense isolated from Malaysian oil palm for detection of basal stem rot disease. Afr. J. Biotechnol. 2014, 13, 3455-3463. [CrossRef]

24. Dutse, S.W.; Yusof, N.A.; Ahmad, H.; Hussein, M.Z.; Hushiarian, R. DNA-based biosensor for detection of Ganoderma boninense, an oil palm pathogen utilising newly synthesised ruthenium complex $\left[\mathrm{Ru}(\mathrm{phen})_{2}(\mathrm{qtpy})\right]_{2}$ based on a PEDOT-PSS/Ag nanoparticles modified electrode. Int. J. Electrochem. Sci. 2013, 8, 11048-11057.

25. Dutse, S.W.; Yusof, N.A.; Ahmad, H.; Hussein, M.Z.; Zainal, Z.; Hushiarian, R.; Hajian, R. An electrochemical biosensor for the determination of Ganoderma boninense pathogen based on a novel modified gold nanocomposite film electrode. Anal. Lett. 2014, 47, 819-832. [CrossRef]

26. Hushiarian, R.; Yusof, N.A.; Abdullah, A.H.; Alang Ahmad, S.A.; Dutse, S.W. Facilitating the indirect detection of genomic DNA in an electrochemical DNA biosensor using magnetic nanoparticles and DNA ligase. Anal. Chem. Res. 2015, 6, 17-25. [CrossRef]

27. Markom, M.A.; Md Shakaff, A.Y.; Adom, A.H.; Ahmad, M.N.; Hidayat, W.; Abdullah, A.H.; Fikri, N.A. Intelligent electronic nose system for basal stem rot disease detection. Comput. Electron. Agr. 2009, 66, 140-146. [CrossRef]

28. Akanbi, F.S.; Yusof, N.A.; Abdullah, J.; Sulaiman, Y.; Hushiarian, R. Detection of quinoline in G. boninense-infected plants using functionalized multi-walled carbon nanotubes: A field study. Sensors 2017, 17, 1538. [CrossRef]

29. Najmie, M.M.K.; Khalid, K.; Sidek, A.A.; Jusoh, M.A. Density and ultrasonic characterization of oil palm trunk infected by Ganoderma Boninense disease. Meas. Sci. Rev. 2011, 11, 160-164. [CrossRef]

30. Lelong, C.C.; Roger, J.-M.; Brégand, S.; Dubertret, F.; Lanore, M.; Sitorus, N.; Raharjo, D.; Caliman, J.-P. Evaluation of oil-palm fungal disease infestation with canopy hyperspectral reflectance data. Sensors 2010, 10, 734-747. [CrossRef] [PubMed]

31. Santoso, H.; Gunawan, T.; Jatmiko, R.H.; Darmosarkoro, W.; Minasny, B. Mapping and identifying basal stem rot disease in oil palms in North Sumatra with QuickBird imagery. Precis. Agric. 2011, 12, 233-248. [CrossRef]

32. Ahmadi, P.; Muharam, F.M.; Ahmad, K.; Mansor, S.; Seman, I.A. Early detection of Ganoderma basal stem rot of oil palms using artificial neural network spectral analysis. Plant Dis. 2017, 101, 1009-1016. [CrossRef]

33. Hashim, I.C.; Shariff, A.R.M.; Bejo, S.K.; Muharam, F.M.; Ahmad, K. Classification for non-infected and infected Ganoderma boninense of oil palm trees using ALOS PALSAR-2 backscattering coefficient. Iop Conf. Ser. Earth Environ. Sci. 2018, 169, 012066. [CrossRef]

34. Taton, T.A.; Mirkin, C.A.; Letsinger, R.L. Scanometric DNA array detection with nanoparticle probes. Science 2000, 289, 1757-1760. [CrossRef] [PubMed]

35. Wang, S.; Hosford, J.; Heath, W.P.; Wong, L.S. Large-area scanning probe nanolithography facilitated by automated alignment of probe arrays. RSC Adv. 2015, 5, 61402-61409. [CrossRef]

36. Lee, I.-N.; Hosford, J.; Wang, S.; Hunt, J.A.; Curran, J.M.; Heath, W.P.; Wong, L.S. Large-area scanning probe nanolithography facilitated by automated alignment and its application to substrate fabrication for cell culture studies. J. Vis. Exp. 2018, 136, e56967. [CrossRef]

37. Li, F.; Zhang, H.; Dever, B.; Li, X.; Le, X.C. Thermal stability of DNA functionalized gold nanoparticles. Bioconjugate Chem. 2013, 24, 1790-1797. [CrossRef]

38. Demers, L.M.; Ginger, D.S.; Park, S.-J.; Li, Z.; Chung, S.-W.; Mirkin, C.A. Direct patterning of modified oligonucleotides on metals and insulators by dip-pen nanolithography. Science 2002, 296, 1836-1838. [CrossRef]

39. Ho, Y.W.; Nawawi, A. Isolation, growth and sporophore development of Ganoderrna boninense from oil palm in Malaysia. Pertanika 1986, 9, 69-73.

40. Amer, O.E.; Mahmoud, M.A.; El-Samawaty, A.M.A.; Sayed, S.R.M. Non liquid nitrogen-based-method for isolation of DNA from filamentous fungi. Afr. J. Biotechnol. 2011, 10, 14337-14341.

41. Storhoff, J.J.; Lucas, A.D.; Garimella, V.; Bao, Y.P.; Müller, U.R. Homogeneous detection of unamplified genomic DNA sequences based on colorimetric scatter of gold nanoparticle probes. Nat. Biotechnol. 2004, 22, 883-887. [CrossRef] [PubMed] 
42. Long, E.O.; David, I.D. Repeated genes in eukaryotes. Annu. Rev. Biochem. 1980, 49, 727-764. [CrossRef] [PubMed]

43. Wolf, L.K.; Gao, Y.; Georgiadis, R.M. Sequence-dependent DNA immobilisation: Specific versus nonspecific contributions. Langmuir 2004, 20, 3357-3361. [CrossRef] [PubMed]

44. Utomo, C.; Werner, S.; Niepold, F.; Demising, H.B. Identification of ganoderma, the causal agent of basal stem rot disease in oil palm using a molecular method. Mycopathologia 2005, 159, 159-170. [CrossRef] [PubMed]

45. Chong, K.P.; Lum, M.S.; Foong, C.P.; Wong, C.W.L.; Atong, M.; Rossall, S. First identification of Ganoderma boninense isolated from Sabah based on PCR and sequecne homology. Afr. J. Biotechnol. 2011, 10, 14718-14723. [CrossRef]

(C) 2019 by the authors. Licensee MDPI, Basel, Switzerland. This article is an open access article distributed under the terms and conditions of the Creative Commons Attribution (CC BY) license (http:// creativecommons.org/licenses/by/4.0/). 